\title{
Indigenous People, Economic Development and Sustainable Tourism: A Comparative Analysis between Bali, Indonesia and Australia
}

\author{
Putri Triari Dwijayanthi* \\ Student at Faculty of Law Udayana University \\ Kali Jones** \\ Student at Charles Darwin University School of Law \\ Ni Gusti Ayu Dyah Satyawati*** \\ Lecturer at Faculty of Law Udayana University
}

\begin{abstract}
Tourism is one of the world's fastest growing industries and has been used as a vehicle for indigenous people to engage in economic development opportunities within their local communities. The concept of sustainable tourism has brought greater awareness towards maintaining the economic and social advantages of tourism development whilst ensuring the industry is both socio-cultural and environmentally sustainable. A central component to the definition of sustainable tourism is the empowerment of indigenous people to take advantage of the benefits of the tourism industry. This article will demonstrate that in certain instances there is conflict between indigenous peoples' culture, particularly communal ownership of land and the tourism industry. This research uses comparative analysis between Bali, Indonesia and the Northern Territory of Australia to analyse the social and legal impediments, which affect the potential of local indigenous people to contribute to sustainable tourism. The conclusion drawn in this article is that both Indonesia and Australia have attempted to provide legal frameworks to promote tourism and development alongside indigenous people, however in both cases the tourism industry has not always been easily applicable to indigenous people's concept of land ownership and communal sharing of economic assets.
\end{abstract}

Keywords: Indigenous People, Tourism, Bali, Australia.

\section{INTRODUCTION}

\subsection{Background}

As one of the world's fastest growing industries, international tourism has begun to place a greater emphasis on mitigating the negative effects of the industry. The concept of sustainable tourism has brought greater awareness towards maintaining the economic and social advantages of tourism development whilst ensuing the industry is socially, culturally, and environmentally sustainable. A central objective within sustainable tourism industry is to empower local indigenous people's ability to harness the economic advantages of tourism whilst maintaining their natural heritage, environment and biodiversity. Sustainable tourism also advocates respecting the socio-cultural authenticity of host communities, which together along with stakeholder will ensure viable, long-term

\footnotetext{
Correspondence: putritriari@gmail.com

** Correspondence: kali.laurenwatson@gmail.com

*** Correspondence: dyah_satyawati@unud.ac.id
} 
economic operations resulting in socio-economic benefits to all parties. ${ }^{1}$ Despite an underlying philosophy of enhancing indigenous advancement through sustainable tourism, there still remains significant social and legal impediments which restrict indigenous people from fully engaging in the sustainable tourism industry.

The United Nations World Tourism Organisation defines sustainable tourism as "tourism that takes full account of its current and future economic, social and environmental impacts, addressing the needs of visitors, the industry, the environment and host communities." It is broadly agreed that sustainable tourism is a valuable vehicle to pursue investment and business opportunities for indigenous communities. Environmental and cultural protection are critical for survival of indigenous peoples, since their traditional way of living is likely to have a closer relationship with surrounding environment and a higher dependency on nature. ${ }^{3}$ Indigenous people also have historical cultural knowledge about their community structures, beliefs and surrounding environment. Sustainable tourism, unlike other resource intensive industries, has the potential to achieve development in communities in a suitable manner if managed properly. ${ }^{4}$

The acknowledgment and recognition of indigenous people's rights are also core components to sustainable tourism outlined in several international treaties and declarations. For example, Article 3 of the United Nations Declaration on Indigenous People, it is stated that: "Indigenous peoples have the right to self-determination. By virtue of that right they freely determine their political status and freely pursue their economic, social and cultural development."5

As indigenous rights have been enshrined and recognised across the globe, the collective rights of the indigenous people shall be managed properly. While indigenous people have participated in the tourism industry, the expansion of economic activities associated with tourism has sometimes resulted in economic leakage from the region, or an unfair distribution of wealth. Compounding the unequal distribution of wealth, there is also conflicting beliefs about collective models of land ownership versus the individual nature of the tourism industry.

\subsection{Central Legal Issue and Purpose of Writing}

This article will primarily assess the impacts of the tourism industry on the collective rights of indigenous people seen from a legal perspective. Some other

1 United Nations, “Sustainable Tourism,"https://sustainabledevelopment.un.org/topics/sustainabletourism.

2 World Tourism Organization, "Definition: Sustainable Development of Tourism,"http://sdt. unwto.org/content/about-us-5

3 Rie Yamaoto, "Indigenous Tourism and Destination Development,"IIIEE Master's Theses 2005, https:/ /lup.lub.lu.se/luur/download?func=downloadFile\&recordOId=1327691\&fileOId=1327692

4 Ibid.

5 Declaration on the Rights of Indigenous Peoples, GA Res 61/295, UN GAOR, 61st Sess, 107th PlenMtg, Supp No 49, UN Doc A/RES/61/295 (13 September 2007). 
perspectives, such as economic and socio-cultural, will also be used. This paper aims to evaluate the contemporary legal framework and the management systems witnessed in Australia and Indonesia and recommend areas for reform, which will better empower indigenous people to participate in the sustainable tourism sector. Furthermore, it is also intended to evaluate any barriers which indigenous people face when participating in sustainable tourism, including in particular social and legal impediments.

\subsection{Methodology and Structure of the Article}

This article is best described as comparative legal research. In order to identify contemporary issues, which may impact on indigenous peoples capacity to fully participate in development opportunities that may exist on their land, this article provides a comparative analysis between local indigenous communities in Indonesia and Australia and evaluate the socio-economic and legal frameworks in each country.

It will discuss the collective rights of the indigenous people of Bali, Indonesia, and compare it with the indigenous people in Australia, using the cases of Kakadu National park and Tenganan Village. The overarching analysis focuses on the tourism impacts on indigenous people and the conflict between collective ownership of land and the individual nature of business in the tourist industry.

In order to achieve its objectives, this article is structured as follow. Section 2.1 will provide a descriptive analysis with regards to the issue of tourism industry and indigenous people in Bali. In this regard, the analysis will first identify communal rights of the Balinese people in tourism as provided in Section 2.2. Similarly, the issue of tourism industry and indigenous people in Australia will also be described by illustrating the policy on the national parks as discussed in Section 2.3 and 2.4. Afterwards, Section 2.5 and 2.6 will analyse social impediments for indigenous people and legal impediments against the development of sustainable tourism. Subsequently, Section 2.7 discusses a comparative analysis between Bali and Northern Territory of Australia. Finally, conclusion and recommendations will be given in Section 3.1 and 3.2

\section{LOCAL WISDOMS FOR ASEAN HUMAN RIGHTS TO DEVELOPMENT ADVOCACY}

\subsection{Tourism Industry and Indigenous People in Bali}

Profit generated from tourism in Bali has provided substantial revenue for Indonesia. Governor of Bali, Made Mangku Pastika stated the amount of the financial contribution from tourism in Bali was estimated at IDR 47 trillion for $2015 .{ }^{6}$ Bali

6 Rofiqi Hasan, "Bali Inginkan Bagi Hasil Pendapatan Pariwisata,"http://nasional.tempo.co/read/ news /2015/09/09/058699194/bali-inginkan-bagi-hasil-pendapatan-pariwisata 
Province recorded economic growth in the third quarter of 2015 at approximately $5.62 \%$ to $6.62 \% .^{7}$ Unfortunately, there is no specific regulationwithin the current Indonesian legal framework that requires profit sharing with the indigenous people.

Article1 paragraph (4) of the Indonesian Tourism Act specifically details the importance of positive interaction between tourists, the community and the role of National and local Government. Article 2 of the Act details a list of principles i.a benefit, sustainability, sustainable development and equality, which the tourism industry in the territory of Indonesia, including Bali, should follow. In order to achieve the objectives of the tourism regulation, the Act also covers the manner in which tourism is developed, which clearly states that such development must take into account the uniqueness of culture. ${ }^{8}$ Thus, the arrangement of the strategic areas of tourism is required to pay attention to cultural, social and religious aspects of the local communities. ${ }^{9}$

The idea of community empowerment starts from the planning, utilization and control for indigenous communities. Such elements are the core pillars outlined in Article 5 of the Global Code of Ethics for Tourism adopted by the World Tourism Organization, which specifies that the world's local populations should be associated with tourism activities should be shared equitably with indigenous communities. ${ }^{10}$ In addition to the sectoral laws, regulation on tourism is also stipulated in the Regulation of the Minister of Home Affairs No. 33 of 2009 on Guidelines for Ecotourism Development in the Region. The regulation outlines the importance of ecotourism with regard to elements of education, understanding, and support for the efforts of conservation of natural resources, as well as increased income of local communities. Thus, based on the laws and regulations in Indonesia, local communities must be empowered and their general welfare considered within the management practices of tourism operations.

\subsection{Communal Rights of the Balinese People in Tourism}

The development of tourism in Bali has significantly affected the local people. Fact shows that the tourism industry has become a livelihood mainly for those who live close to tourism destinations. ${ }^{11}$ It has also affected the existence of Balinese

\footnotetext{
7 Ibid.

8 Act of the Republic Indonesia No. 10 of 2009 concerning Tourism, Art. 6.

9 Ibid., Art. 12 paragraph (3).

${ }^{10}$ United Nations World Tourism Organization, "Global Code of Ethics for Tourism," http://ethics. unwto.org/en/content/global-code-ethics-tourism.

11 Tjok Istri Putra Astiti and I Ketut Sudantra, "Reflecting on Tourism Activities in Bali: A Discourse on Communal Rights, Culture and Hindu Values," in Sustainable Tourism and Law, eds. Michael G. Faure, Ni Ketut Supasti Dharmawan and I Made Budi Arsika (Den Haag: Eleven International Publishing, 2014), 235.
} 
traditional community, called Desa Pakraman or Desa Adat, especially in the matter of land issue.

This Desa Pakraman has had a peculiar tradition and social demeanour of Hindus for generations, by owning an area of land as a collective. The system determines their rights to manage their own organization and land. ${ }^{12}$ The -Desa Pakraman as a traditional village in Bali is a legal community (masyarakat hukum), whose customary rights (hak-hak adat) have been recognized and protected by the 1945 Constitution of the Republic of Indonesia (hereinafter, Indonesian Constitution).

There are two provisions laid down in the Indonesian Constitution addressing traditional communities and their rights. Article 18B paragraph 2 states that: "The States recognizes and respects traditional communities along with their traditional customary rights as long as they remain in existence and are in accordance with the societal development and the principles of the Unitary State of the Republic of Indonesia, and shall be regulated by law."13

Following the provisions stipulated in the Indonesian Constitution, the right of indigenous people is also mentioned in Article 6 paragraph (1) and (2) of the Act of the Republic of Indonesia No. 39 of 1999 concerning Human Rights, which states: "In order to enforce Human Rights, differences and needs of indigenous people must be paid attention to and protected by the law, government and society; The cultural identity of the local community including their tanah ulayat (the communal right for land) is protected accordance with the development."

Furthermore, the communal rights of a traditional community in Bali are represented by Desa Pakraman. ${ }^{14}$ It consists of individuals who live in a territory or village and have traditionally become members, in which they voluntarily accept the obligations determined by Desa Pakraman. ${ }^{15}$

Some problems have arisen when tourism activities affected the communal rights of the traditional community in Bali. For example, the construction hotels, villas and resorts are set up in productive rice fields, where the water is used to supply swimming pools. ${ }^{16}$ Permits issued by the local level of the Indonesian government have been used by tourism entrepreneurs to justify their activities, where in many cases, Desa Pakraman beliefs, norms and values are incompatible with the tourism activities. ${ }^{17}$ In some instances the communal rights of the Balinese traditional community have been endangered instead of promoted by the tourism industry. ${ }^{18}$

\footnotetext{
12 See Regulation of the Province of Bali No. 2 of 2012 concerning Culture Tourism of Bali, Art. 1 (5).

13 The 1945 Constitution of the Republic of Indonesia, Art. 18B paragraph 2

14 Tjok Istri Putra Astiti and I Ketut Sudantra, Op.Cit.,13.

15 Ibid.

16 Ibid.

17 Ibid.

18 Ibid.
} 
However, not in all cases is there an erosion of the rights of traditional people due to tourist activities. For example, the village of Tenganan in Bali started to develop economic tourism in the early 1980's. Since the integration of tourism, Tenganan has maintained a traditional way of living. Astiti, et al., observed, "[r]emarkably, the development of tourism in the village has not led to an individualization process (the process by which the certificates of collective ownership would be converted into individual ownership)." ${ }^{19}$ In many ways, Tenganan is different from other villages in Bali, where individualism has been responsible for transforming communal land, such as tanah ayahan desa (the land controlled by the traditional village) into private land and land belonging to the community was sold by individuals. ${ }^{20}$

However the villagers in Tenganan realize that the "very fact that their village is traditional and unique is precisely what makes it so attractive for tourists" 21 Unlike some other areas of Bali, Tenganan also maintains their customary laws (awig-awig), which prohibits the transfer of land to outsiders, meaning the local indigenous people still maintain their collective rights to land. ${ }^{22}$

\subsection{Tourism Industry and Indigenous People in Australia}

Like Bali, tourism in Northern Territory of Australia is a significant contributor to the country's economy, identity and future prosperity. For example in 2014, total tourism spending contributed almost 3 per cent of Australia's GDP - about one-third of this ( $\$ 11$ billion) was by international visitors. International tourism's share of total service exports was just over 60 per cent in $2014 .^{23}$

The tourism industry in Australia is regulated by the Competitions and Consumer Act 2010 and consumer law, with state and territory related legislation. Sustainable tourism and environmental protection relies on the Environmental Protection and Biodiversity Conservation Act 1999. Within Australia's tourism sector, the idyllic natural beauty and unique indigenous culture has historically been depicted to promote Australia as an intern Aboriginal and Torres Strait Islander Heritage Protection Act 1984 ational tourism destination. ${ }^{24}$ In Australia, the Indigenous tourism

\footnotetext{
${ }^{19}$ Tjokorda Istri Putra Astiti, Anak Agung Istri Ari Atu Dewi and Michael Faure "Tourism Development and Customary Land Law in Bali", Southwestern Journal of International Law 20, No. 1 (2013): 121, http:/ / www.esl.eur.nl/fileadmin/ASSETS/frg/arw/RILE/FRONT.pdf

20 Ibid.

21 Ibid. id., 134

22 Gadjah Mada University, "Menjaga Hutan Ala Masyarakat Kajang dan Tenganan", http://www. ugm.ac.id/en/berita/4593-menjaga.hutan.ala.masyarakat.kajang.dan.tenganan.

${ }^{23}$ Australia International Tourism Industry, "Productivity Commissions Research Paper," 2http:// www.pc.gov.au/research/completed/international-tourism/international-tourism.pdf.

${ }^{24}$ Dina James, JocSchmeiechen, "Enriching the Experience, "http: / www.crctourism.com.au/wms/ upload/resources / 100024\%20James\%20Enriching\%20the\%20Experience\%20WEB.pdf.
} 
industry is a $\$ 3.8$ billion annual economy, catering to 689,000 international visitors in 2010 and 306,000 overnight domestic indigenous trips. ${ }^{25}$

Currently, there are two spheres in which potential for indigenous sustainable tourism can be observed. In the first sphere, National parks and heritage listed areas are protected under the Aboriginal and Torres Strait Islander Heritage Protection Act 1984 and the Protection of Movable Cultural Heritage Act 1986. Majority of national parks are situated on Aboriginal land, allocated under the Aboriginal Land Rights (Northern Territory) Act 1975 (ALRA). The land rights incorporation of indigenous people's notions of land ownership into national and domestic legislation was an achievement of the indigenous land rights movement. The Act granted interest in land from Commonwealth and State back to the traditional owners or the land. Further to this the native title Act was another piece of legislation enacted after the historical high court Mabo case. ${ }^{26}$

Title to Aboriginal land in the National parks is held by Aboriginal land trusts. The land trusts have leased their land to the Director of National Parks so that it can be used as a national park for the enjoyment and benefit of all Australians. Different parks have various models of co-operative management with indigenous people and Government. These models help promote inclusivity, sustainability and maintaining bio-diversity with profit being generated back to the management and promotion of the parks. This paper will investigate Kakadu national park in the Northern Territory as an ideal model for sustainable tourism.

The second sphere, which falls outside the preview of national parks, relates to legal and social implications associated with inadequacies of certain amendments and provisions of the ALRA. It will be argued that these implications have directly impacted on indigenous people's ability to participate in industries such as sustainable tourism and provided recommendation for reform through comparative analysis.

\subsection{National Parks}

The enactment of the ALRA had substantial impacts on indigenous people's ability to control and develop their own land. It was also a step forward in providing a legal mechanism for indigenous empowerment and control. Since the enactment of land rights, the legal framework, which provides the foundation for growth in indigenous tourism, is spread amongst specific state and territory laws, broader national legislation and Government agencies.

\footnotetext{
${ }^{25}$ Michelle Wranik, “Indigenous Tourism in Australia,"http://travel.cnn.com/sydney/visit/indigenous-tourism-australia-906531.

${ }^{26}$ Mabo and Others v. Queensland (No. 2) (1992) 175 CLR 1.
} 
Indigenous traditional owners and Government employees jointly manage Kakadu National Park. ${ }^{27}$ According to parks Australian Sustainable Overview 20112016 a key strategy is to develop tourism in collaboration with boards of management, that identify the goals of traditional owners in tourism to be implemented by jointly. However, the report also mentioned there was limited interest in indigenous people to form their own tourism business within the park and to date there has only been small examples of tourism ventures in National parks owner by indigenous people. ${ }^{28}$ Traditional owners were more engaged in the preservation, education and environmental management of the park. The case of Kakadu suggests that a co-operative model which prioritizes sustainable tourism and empowers indigenous peoples to control their own national heritage and culture whilst promoting investment is achievable. However, despite having legal and governmental internal infrastructure, there are pre-existing social issues which have widened the "enterprise gap" existing between indigenous communities and the mainstream industry sector. ${ }^{29}$

\subsection{Social Impediments for Indigenous People}

Outside the jurisdiction of National Parks, investment and development of indigenous tourism becomes more complex. Aboriginal-owned tourism ventures are a growing segment of the Australian tourism industry, mainly since the 1990s. ${ }^{30}$ However, the industry still has structural and legal impairments, which have been burdened by historical social discrimination of indigenous people. For example, traditional marketing approaches of indigenous tourism have been criticized for only depicting imagery of indigenous people as "tribal" and "primitive" people who play "didgeridoos." Such perceptions have rendered Aboriginal people 'invisible' in contemporary Australian life and impact on the public perception of indigenous people's ability to engage in corporate enterprise. Low living standards, welfare dependency, systemic disadvantages and racial discrimination are significant factors, which have produced adverse influences upon indigenous peoples engagement with mainstream western society. ${ }^{31}$ Therefore the manner in which indigenous people are included and empowered to be a leading force within any mainstream industry can, in certain circumstances be limited.

27 Director of Parks Report, “Parks Australia: Sustainable tourism overview (2011-2016),"https:// www.environment.gov.au/system/files/resources/ed9f71b7-edbc-4a9f-801d-0457aa7b763b/files/sustainable-tourism.pdf

28 Ibid.

29 Don Fuller, Susan Bandias, and Darius Pfitzner, "Utilizing Aboriginal Land in the Northern Territory,"http://www.cdu.edu.au/sites/default/files/PaperLeasingAboriginalLand.pdf.

30 Wranik, Op.Cit, 27.

31 Fuller, Bandias \& Pfitzner, Op.Cit, 302. 


\subsection{Legal impediments against the development of sustainable tourism}

Connection to land is fundamental to indigenous culture and history. Indigenous people's concept of land ownership starkly differs from traditional notions of property ownership. Culturally boundaries cut across the vast area of land were fixed by "dreaming" creation stories. Each indigenous person belonged to a family group who has a spiritual connection with the land, "hence land was not owned; one belonged to the land." ${ }^{2}$

Given 55\% of land in the Northern Territory is claimed under the native title Act 1999 Native title ${ }^{33}$ the strength and rigor of the internal legal infrastructure, which is responsible for governing development in indigenous communities is critically important. Over-time there has been significant amendments to ALRA since it passed parliament with bi-partisan supports. The amendments reflect the tensions between western perceptions of socio-economic development and indigenous peoples concept of collective land ownership. A central theme to indigenous peoples around the world is emphasis on the importance of communal land rights. This has directly conflicted with the idea of individual property rights, which are portrayed as a necessity for economic development. To illustrate this point in legal context the 2006 amendments to the ALRA will be evaluated.

Several changes to the ALRA have been made since its enactment. However, provision 19A was the most controversial, since it provided with the consent of the land councils and traditional owners alongside Ministerial approval. A 99-year lease over a township on Aboriginal land could be granted to a NT or Commonwealth government 'entity'. ${ }^{44}$

As argued by the Social Justice Commissioner, Tom Calma, the original intent of land rights was to return autonomy and decision-making power to Aboriginal people for their own development. He argued;

"Self-determination is not: simply about achieving better socioeconomic outcomes; it is also about the right and power of Indigenous Australians, as a distinct peoples, to decide what development they want, how they want to achieve it, and what aspects of their laws, culture and values they will retain or give up in the process." 35

Since the enactment of the amendment, the lease provisions have been accused of not following the underpinning objective of the Land rights Act whilst creating a

32 Dudgeon, Wright, Paradies, Garvey \& Iain Walker, "Social, cultural and Historical Context of Aboriginal and Torres Strait Islander Australians,” http://aboriginal.telethonkids.org.au/media/54859/ part_1_chapter3.pdf.

33 Fuller, Bandias\&Pfitzner, Op.Cit., 40.

34 Sean Brennan, "Economic Development and Land Council Power: Modernising the Land Rights Act or Same Old Same Old?," Indigenous Law Reporter, 10 (4) (2006),14,17-18.

35 Ibid., 15. 
power imbalance between Government, other "entities" and local indigenous elders. Given the already existing severe systemic disadvantage in indigenous communities, the need for basic infrastructure and services is prioritised over a western concept of tenure and commercial enterprise. This was illustrated in the Elcho island lease in which the Minister, Mr Brough, confirmed that agreement to a township lease was a precondition for Commonwealth funding of 50 new houses on Elcho Island. Aside from indigenous people prioritising basic needs above development. The amendments, at their fundamental core demonstrated the differences between communal ownership over land and the assumption held by industry that indigenous people would forgo their right to engage in commercial development over large areas of vacant land for ninety-nine years. ${ }^{36}$ So as industry can have security of tenure which in itself indicates that indigenous people are not capable of facilitating their own development.

Creating enterprise and industry through the empowerment of indigenous people using their own assets such as land was a strong driver behind the Land Rights movement. Critical statutory bodies, which were created under the authority of the ALRA, are land councils. There are two land councils covering the Northern Territory, the Northern Land Council and the Central Land Council. Despite playing a significant role in highly cultural sensitive and complex environment, land councils have both encroached and facilitated indigenous development and engagement with industries such as sustainable tourism. Councils are said to have "shifted awkwardly between acting as managers, advocates and protectors. In so doing, they have been accused periodically of autocracy, obstructionism and of favouring the interests of their own executives above all else". ${ }^{37}$

In response to inadequacies experienced with the enormity of land councils, another draft of amendments recently passed the Australian Senate. Indigenous Affairs Minister Nigel Scullin stated the intention of the amendments was for Indigenous landowners and community members to play an integral role in fostering economic development in their communities. The changes support Aboriginal people in the Northern Territory to make decisions about their own land within commercial timeframes.

The changes are an attempt to de-centralise the Land Councils power in order to accommodate small indigenous organisations. An example of a small organisation, which is built on the principle of indigenous sustainable tourism is Lirrwi tourism, an indigenous controlled company which explores Arnhem land with tourists. Whilst, land councils have been a forum for engagement and discussion for issues relating

\footnotetext{
${ }^{36}$ Central Land Council, "Land Reform in The Northern Territory: Evidence Not Ideology," http:// www.clc.org.au/files/pdf/ALRA_CLC_Tenure_paper_-_final.pdf.

${ }^{37}$ Amost Akin, "Aboriginal land rights out of step ", http://www.theaustralian.com.au/news/features/aboriginal-land-rights-out-of-step/story-e6frg6z6-1227007700222.
} 
to the environment such as land claims; national park management; sacred site protection and site clearances, land management programs and future investment projects which pertain to indigenous land. ${ }^{38}$ The enormity of the councils has been a source of political debate. There has been a stronger push from local indigenous groups to form their own organisations in order to better represent the needs and interests of their communities. Due to the diverse nature of land councils, they have been criticised as being politically polarised, which often means that it is difficult to get approval for certain groups to use their land for commercial activities. In the words of indigenous activist Noel Person Indigenous Australians have become "land rich but dirt poor." 39

\subsection{Comparative Analysis}

In Bali, the ownership of the land can be divided into two groups they are, the land owned by by the village and the land owned by individuals. ${ }^{40}$ The regulation regarding the ownership of the land in Bali is regulated in Adat Law or Awig-awig, which is still accepted and implemented by the people. ${ }^{41}$ In Tenganan Village, the right to ownership of the land is divided into an individual right and also collective rights. ${ }^{42}$ The right to ownership of land in Tenganan Village is regulated by Adat Law, which also known as Awig-Awig. ${ }^{43}$ The Awig-awig of Tenganan village prohibits the transfer of right to land by selling, mortgaging, or any other means, to those living outside the village. ${ }^{44}$ The indigenous people in Tenganan strictly follow this regulation until today. By preserving their traditional culture, Tenganan has been viewed as an auth 14.817 entic tourist destination.

Australia has similar issues in a different context. Like Indonesia, Indigenous people in Australia witnessed their rights enshrined law. However, as demonstrated above, social factors remain a barrier for full participation in industries where indigenous people are more likely to portray a willingness to be involved in, such was the case in Kakadu National Park. Compounding these challenges is the assumption that the tourism industry itself relies on an individualised industry, which does not incorporate consideration of the communal ownership of land rights. This was clearly evident in the 2006 amendments to the ALRA. However, in evaluating

\footnotetext{
38 Ibid.

39 Ibid.

40 I Ketut Artadi, Hukum Adat Bali, (Denpasar Pustaka Bali Post, 2012), 133.

41 Tolib Setiady, Intisari Hukum Adat Indonesia: Dalam Kajian Kepustakaan, (Bandung: Alfabeta,
} 2013), 3.

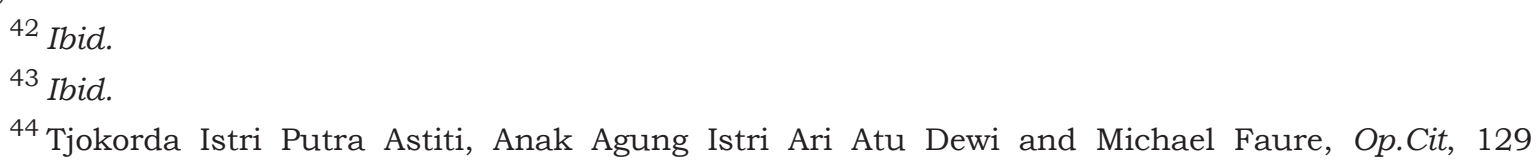


the case study of Tenganan, there is potential to reconcile the difference between communal ownership of land whilst maintain cultural heritage and authenticity. By maintaining this form of collective land rights indigenous people are more likely to be involved in industries, which promote sustainable tourism.

\section{CONCLUDING SECTION}

\subsection{Conclusion}

Indigenous people have a meaningful contribution to make towards the sustainable tourism industry. Their connection to land and culture provides for an authentic experience and allows visitors to share their cultural heritage. The concept of sustainable tourism strongly includes the empowerment and engagement of indigenous people. This is reflected both national and international laws. Both Indonesia and Australia have attempted to provide legal frameworks to promote tourism and development alongside indigenous people, however in both cases the tourism industry has not always been easily applicable to indigenous people's concept of land ownership and communal sharing of economic assets.

\subsection{Recommendations}

In the implementation of ecotourism activities in the area of Tenganan, although able to maintain their communal rights the local community has not fully enjoyed economic benefits they should enjoy. The perception of injustice among the tourism entrepreneurs and villagers in Tenganan in terms of profit sharing is one of the problems that are yet to be overcome. A system in which there is Government support and joint management, similar to what has been established in Australia, evident in the case of Kakadu national park could be adapted to suit an Indonesian context. In addition, in Indonesia it is important for the government to impose regulations, which specifically regulate the rights of indigenous people and the manner in which wealth is distributed in indigenous communities through the tourism industry. 


\section{Bibliography}

\section{Books}

Artadi, I Ketut. Hukum Adat Bali. Denpasar: Pustaka Bali Post, 2012

Astiti, Tjok Istri Putra and I Ketut Sudantra, "Reflecting on Tourism Activities in Bali: A Discourse on Communal Rights, Culture and Hindu Values," in Sustainable Tourism and Law, edited by Michael G. Faure, Ni Ketut Supasti Dharmawan and I Made Budi Arsika. Den Haag: Eleven International Publishing, 2014

Setiady, Tolib. Intisari Hukum Adat Indonesia: Dalam Kajian Kepustakaan, Bandung, Alfabeta, 2013

\section{Journals}

Astiti, Tjokorda Istri Putra, Anak Agung Istri Ari Atu Dewi and Michael Faure. "Tourism Development and Customary Land Law in Bali", Southwestern Journal of International Law 20, No. 1 (2013): 119-140. http://www.esl.eur.nl/fileadmin/ASSETS/frg/arw/RILE/FRONT.pdf

Brennan, Sean. "Economic Development and Land Council Power: Modernising the Land Rights Act or Same Old Same Old?.” Indigenous Law Reporter 10 (4) (2006)

\section{Paper}

Fuller, Don, Susan Bandias, and Darius Pfitzner. "Utilizing Aboriginal Land in the Northern Territory.", https://www.cdu.edu.au/sites/default/files/PaperLeasingAboriginalLand.pdf

\section{Legal Documents}

Declaration on the Rights of Indigenous Peoples, GA Res 61/295, UN GAOR, 61st Sess, 107th PlenMtg, Supp No 49, UN Doc A/RES/61/295 (13 September 2007)

United Nations World Tourism Organization Global Code of Ethics for Tourism 
Indonesia. The 1945 Constitution of the Republic of Indonesia . Act of the Republic of Indonesia No. 39 of 1999 concerning Human Rights . Act of the Republic Indonesia No. 10 of 2009 concerning Tourism

. Regulation of the Minister of Home Affairs No. 33 of 2009 concerning Guidelines for Ecotourism Development in the Region

. Regulation of the Province of Bali No. 2 of 2012 concerning Culture Tourism of Bali

Australia. Aboriginal Land Rights (Northern Territory) Act 1976 . Aboriginal and Torres Strait Islander Heritage Protection Act 1984 . Protection of Movable Cultural Heritage Act 1986 Environmental Protection and Biodiversity Conservation Act 1999

\section{Case Law}

Mabo and Others v. Queensland (No. 2) (1992) 175 CLR 1

\section{Internets}

Akin, Amost. "Aboriginal land rights out of step."http://www.theaustralian.com. au / news / features / aboriginal-land-rights-out-of-step/story-e6frg6z61227007700222

Australia International Tourism Industry. "Productivity Commissions Research Paper." 2http://www.pc.gov.au/research/completed/international-tourism/ international-tourism.pdf

Director of Parks Report. "Parks Australia: Sustainable tourism overview (20112016)."https: / / www.environment.gov.au/system/files / resources / ed9f71b7-edbc-4a9f-801d-0457aa7b763b/files/sustainable-tourism.pdf

Central Land Council. "Land Reform in The Northern Territory: Evidence Not Ideology.” http://www.clc.org.au/files/pdf/ALRA_CLC_Tenure_paper_-_final.pdf

Dudgeon, Wright, Paradies, Garvey \& Iain Walker. "Social, cultural and Historical Context of Aboriginal and Torres Strait Islander Australians." http://aboriginal.telethonkids.org.au/media/54859/part_1_chapter3.pdf 
Gadjah Mada University. "Menjaga Hutan Ala Masyarakat Kajang dan Tenganan.” http://www.ugm.ac.id/en/berita/4593-menjaga.hutan.ala.masyarakat. kajang.dan.tenganan.

Hasan, Rofiqi. "Bali Inginkan Bagi Hasil Pendapatan Pariwisata." http://nasional. tempo.co/read/news / 2015/09/09/058699194/bali-inginkan-bagi-hasilpendapatan-pariwisata

James, Dina, JocSchmeiechen. "Enriching the Experience." http://www.crctourism.com.au/wms / upload / resources / 100024\%20James\%20Enriching\%20 the\%20Experience\%20WEB.pdf

United Nations. "Sustainable Tourism," https://sustainabledevelopment.un.org/ topics/sustainabletourism

United Nations World Tourism Organization. "Global Code of Ethics for Tourism." http:/ / ethics.unwto.org/en/content/global-code-ethics-tourism

United Nations World Tourism Organization, "Definition: Sustainable Development of Tourism,"http://sdt.unwto.org/content/about-us-5

Wranik, Michelle. "Indigenous Tourism in Australia."http://travel.cnn.com/sydney/visit/indigenous-tourism-australia-906531

Yamaoto, Rie. "Indigenous Tourism and Destination Development."IIIEE Master's Theses 2005.https://lup.lub.lu.se/luur/download?func=downloadFile\&rec ordOId=1327691\&fileOId=1327692 